\title{
Central eastern Europe five years after enlargement: in full grip of the crisis*
}

\begin{abstract}
Central east European new member states have been shaken by the financial crisis and some of them, in the most turbulent periods, have even been haunted by the spectre of state bankruptcy. Any such developments would pose a real threat to the whole of Europe and would undermine the foundations of the European idea. The crisis in central and eastern Europe highlights the one-sidedness of European integration, with deep economic and trade integration amplifying the negative effects from western Europe while political and social integration to fend off the consequences is lacking. Policy responses from Europe have been neither timely nor adequate, and initiative has been left, to a large extent, to the International Monetary Fund. This is itself evidence of political weakness, revealing the naked reality of a Europe lacking efficient Union-wide institutions. The conditionalities of the IMF bailouts, entailing severe and rigidly-applied spending cuts, undermine fragile welfare systems and threaten an escalation of the crisis as well as political and social stability in the entire region. Europe needs to do more and a crisis intervention fund needs to be established to avoid the potential failure of any of its member states.
\end{abstract}

Keywords: central east Europe, toxic assets, growth and employment, credit crunch, external financing, cross-border bank funding, economic and trade integration, neo-liberal orthodoxy, social Europe, political weakness of EU, EU enlargement

\section{Introduction}

For the eight central east European countries (Czech Republic, Estonia, Hungary, Latvia, Lithuania, Poland, Slovakia and Slovenia), the fifth anniversary of EU accession has been marked by the devastating effect of the worldwide financial and economic crisis that is sweeping through the region. Bulgaria and Romania, which joined the EU in January 2007, are equally affected. We focus our attention here on the ten new member states from the region which entered the EU during the last two enlargement rounds, with some additional references to Serbia and, particularly, to the Ukraine, which paints an alarming picture of how bad the crisis can get.

The contagion generated by the US sub-prime mortgage market spread, via different channels of opaque financial instruments, around the whole world (see more in Watt, 2008). The main effect was that 'toxic assets' have caused huge losses in the books of

* This article is a modified version of European Economic and Policy Brief 2009/4 of the European Trade Union Institute, Brussels. 
financial institutions while the previously abundant liquidity has turned into a credit crunch paralysing the entire banking system not only in the US and Europe, but worldwide. The contagion has engulfed the European banking system and the dramatic effects of the financial crisis on the European economy have surprised everybody.

It had, at first, been thought that the central east European new member states would not be affected by the spreading financial turmoil as their financial institutions were not involved in the opaque financial transactions characteristic of the US and most western banks.

However, macroeconomic imbalances, a chronic dependence on external financing and a high level of economic and trade integration with the EU15 formed underlying reasons why these new member states suddenly found themselves deeply affected. They were hit hard within a short timescale due to a series of factors that highlighted how previous high growth became unsustainable once the external environment took a turn for the worse.

In the next sections, we show the major effects of the crisis on the new member states from central east Europe, providing an overview of the factors in their vulnerability as underlying reasons for the intensity of the downturn. We then address the policy responses that have been made and consider the prospects and implications for the process of European integration.

\section{Economic growth and employment}

In the past few years, it has been taken for granted that a convergence process of the central east European transformation economies towards the standards and realities of developed western Europe was taking place. Their average growth rates over the last decade were characteristically between 4 and 5 per cent, with Slovakia and the Baltic States attaining growth dynamics of up to 10 per cent in certain years. Productivity was soaring and national currencies (those not pegged to the Euro) were undergoing a real effective appreciation. The dramatic effects of the crisis on the central east European region now call into question the sustainability of this economic and social convergence process.

The 'hard landing' of 2009 from the high growth levels of 2007 is visible in Figure 1, based on the May 2009 Forecast of the Commission (European Commission, 2009). 
Figure 1 - GDP growth in 2007 and forecast for 2009 (annual growth)

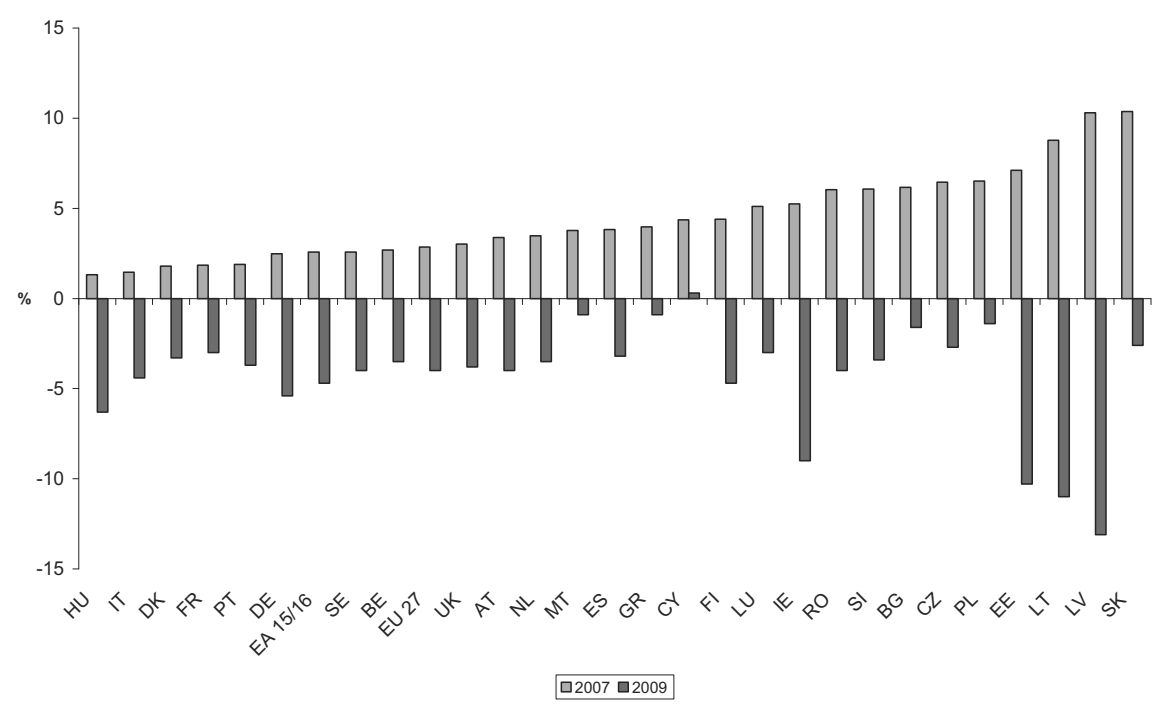

Source: European Commission (2009)

Some of the new member states from central east Europe have been particularly hard-hit. The most dramatic downturn is foreseen in Latvia, where an above $10 \%$ GDP growth in 2007 is likely to turn into a decrease of $13.1 \%$ in 2009. Previous high-growth economies, such as Estonia and Lithuania, are also expected to suffer with a projected drop in GDP respectively of $10.3 \%$ and $11 \%$ in 2009 , while the $6.3 \%$ fall for Hungary is also substantial.

Employment creation had been very weak in central and eastern Europe even in the boom years, as illustrated by Figure 2. Both the US and the EU15 have had higher increases of employment with a fraction of the growth found in the new member states from the region. 
Figure 2 - GDP and employment growth, 1999-2008 (cumulative change, \%)

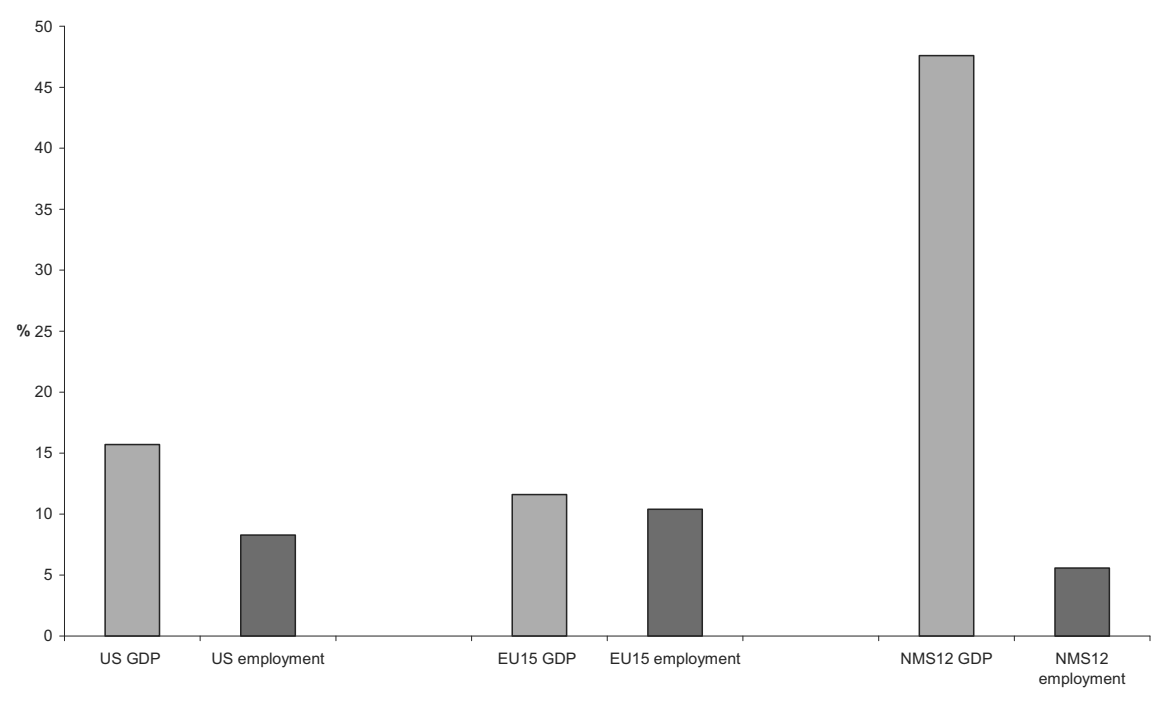

Now, jobs are disappearing on a massive scale. Unemployment in Latvia, Lithuania and Estonia has doubled within one year, jumping to over $12 \%$ in Latvia and to nearly $10 \%$ in Lithuania and Estonia by early 2009. The unemployment rate in Hungary and in Slovakia did not show such dramatic changes but the levels were already close to $10 \%$.

\section{Factors in the vulnerability of central east European economies}

Soon after the crash of Lehman Brothers in mid-September 2008, it appeared how vulnerable indeed were the new member states from central east Europe, while the figures on growth and employment provide an indication of this. The underlying reasons for these severe effects are rooted in the vulnerability of these economies, the most important factors behind which will be addressed in the next sub-sections.

Macroeconomic imbalances at times of financial turbulence

With the continuing paucity of domestic capital, 'catching-up economies' have been notoriously reliant on external capital throughout the whole transformation process. This has included foreign direct investments (FDI), financial investments (into state bonds and diverse corporate assets), foreign bank and government loans, and EU transfers. This high requirement for external financing made these countries dependent on the availability of an abundance of investment capital and on high risk-taking attitudes of investors. Current account deficits in most central east European countries had been notoriously high and, in certain countries, this was accompanied by high levels of external debt. In a number of countries, consumption was largely financed by credits while particularly those with a pegged currency witnessed high price and wage inflation, 
together with rising asset (especially house) prices. Government debt (which used previously to be the focus of attention) is substantially lower for most central east European countries than is usually the case for developed economies, but their total external debt, including enterprise and household debt, has reached high levels in the most recent period. Table 1 shows current account balances for 2008 and 2009 and also indicates the levels of total requirement for external financing (for more on current account deficits in the region, see Shelburne, 2008).

After the shockwaves of the credit crunch and the bankruptcies in the US and the western European financial system, investors' confidence and appetite for risk suddenly evaporated. With this growing risk aversion, foreign investors turned their backs on emerging market assets (including government securities) and retreated to their domestic markets. According to the Bank for International Settlements (BIS), US investors alone repatriated \$750bn in the last three quarters of 2008 (Financial Times, 2009a). BIS data also reveal that cross-border lending by banks shrank by $\$ 4800 \mathrm{bn}$ in the first nine months of 2008. According to the IMF, the retreat from cross-border exposures is occurring more rapidly than the overall de-leveraging process (Financial Times, 2009b). The financing need of the stimulus packages of G7 economies might also add to the diversion of money flows from the financial markets of central east Europe, as the amount of state bond issues in G7 economies is estimated to grow from \$1 000bn in 2008 to \$3 000bn in 2009.

As a result, financial markets in emerging Europe came under huge pressure and daily debt financing has suddenly become difficult. National currencies were shaken with devaluations of up to $50 \%$ in the case of the Ukrainian Hrivnia, while the Polish Zloty, Hungarian Forint, Czech Koruna and Romanian Lei also suffered setbacks of up to $20-25 \%$. Credit ratings of state bonds were downgraded and country risk indicators deteriorated sharply, resulting in high interest rate margins and making debt financing difficult or, in certain cases, impossible. The default risk of state bonds is indicated by 'credit default swap spreads' (CDS) which express the probability of state insolvency which, in the case of Ukraine, is estimated at $39 \%$ and in that of Latvia at $10 \%$ (Table 1). The state bonds of Latvia, Romania, Serbia and Ukraine are, meanwhile, rated as 'junk bonds' (rating B and under, as indicated in Table 1). These developments have triggered the further devaluations of regional currencies (not only those of the affected countries), launching a vicious circle of contagion across the region.

Table 1 - Financial indicators for selected central eastern European countries

\begin{tabular}{|c|c|c|c|c|c|c|c|}
\hline \multirow[t]{2}{*}{ Country } & \multirow[t]{2}{*}{$\begin{array}{c}\text { GDP/ } \\
\text { capita } \\
\text { 2008, \$ } \\
\text { PPS }\end{array}$} & \multirow[t]{2}{*}{$\begin{array}{c}\text { Financing } \\
\text { need, \% } \\
\text { GDP } 1\end{array}$} & \multicolumn{2}{|c|}{$\begin{array}{c}\text { Current } \\
\text { account } \\
\text { balance, \% } \\
\text { GDP }^{2}\end{array}$} & \multirow[t]{2}{*}{$\begin{array}{c}\text { Export } \\
\text { share in } \\
\text { GDP } \\
(2008)\end{array}$} & \multirow[t]{2}{*}{$\begin{array}{l}\text { 5-year } \\
\text { CDS }^{3}\end{array}$} & \multirow[t]{2}{*}{$\begin{array}{l}\text { S\&P } \\
\text { credit } \\
\text { rating }\end{array}$} \\
\hline & & & 2008 & 2009 & & & \\
\hline Bulgaria & 12372 & 29.4 & -24 & -12.9 & 61.0 & 617 & A \\
\hline Czech Republic & 25757 & 9.4 & -3.5 & -2.8 & 80.1 & 309 & $\mathrm{AA}$ \\
\hline Estonia & 20754 & 20.0 & -10 & -6.3 & 72.0 & 700 & AA \\
\hline
\end{tabular}




\begin{tabular}{|c|c|c|c|c|c|c|c|}
\hline \multirow[t]{2}{*}{ Country } & \multirow[t]{2}{*}{$\begin{array}{c}\text { GDP/ } \\
\text { capita } \\
\text { 2008, \$ } \\
\text { PPS }\end{array}$} & \multirow[t]{2}{*}{$\begin{array}{c}\text { Financing } \\
\text { need, \% } \\
\text { GDP }{ }^{1}\end{array}$} & \multicolumn{2}{|c|}{$\begin{array}{c}\text { Current } \\
\text { account } \\
\text { balance, \% } \\
\text { GDP }^{2}\end{array}$} & \multirow[t]{2}{*}{$\begin{array}{c}\text { Export } \\
\text { share in } \\
\text { GDP } \\
(\mathbf{2 0 0 8 )}\end{array}$} & \multirow[t]{2}{*}{$\begin{array}{c}\text { 5-year } \\
\text { CDS }^{3}\end{array}$} & \multirow[t]{2}{*}{$\begin{array}{c}\text { S\&P } \\
\text { credit } \\
\text { rating }\end{array}$} \\
\hline & & & 2008 & 2009 & & & \\
\hline Hungary & 19830 & 29.9 & -6.5 & -3.9 & 80.2 & 574 & A \\
\hline Latvia & 17801 & 24.3 & -14 & -6.7 & 46.6 & 1001 & $\mathrm{BBB}$ \\
\hline Lithuania & 18855 & 27.1 & -12 & -4.8 & 59.0 & 833 & $\mathrm{~A}+$ \\
\hline Poland & 17560 & 13.2 & -5 & -4.9 & 42.3 & 387 & $\mathrm{~A}+$ \\
\hline Romania & 12698 & 20.2 & -12 & -7.5 & 34.4 & 719 & $\mathrm{BBB}+$ \\
\hline Serbia & 10911 & & & & 22.2 & & BB- \\
\hline Slovakia & 22242 & 12.5 & -6 & & 90.5 & 222 & AAA \\
\hline Slovenia & 28894 & - & -6 & & 70.5 & 206 & AAA \\
\hline Ukraine & 7634 & 16.1 & -6.5 & 0.6 & 45.0 & 3899 & $\mathrm{CCC}+$ \\
\hline
\end{tabular}

${ }^{1}$ Total financing requirement, current account balance, principal due on public and private debts plus IMF debits, 2008 estimate.

${ }^{2}$ IMF prognosis.

3 5-year credit default swap spreads in basis points, as of March 2009.

Source: The Economist 28 February 2009, based on IMF, Moody's; and Financial Times 27 February 2009, based on Thomson Datastream.

\section{The role of western banks in the region}

Over $80 \%$ of the banks of central east European countries are affiliates of western banks. These banks were eager to grant credits on a mass scale to the population and to enterprises in all countries of the region, often denominated in foreign currency (especially in countries where interest rates in the local currency were substantially higher). According to a study by the Centre for European Policy Studies (Gros, 2009), the residential mortgage debt in the so-called Višegrad Four countries - the Czech Republic, Hungary, Poland and Slovakia - ranges between $11.7 \%$ of GDP in Poland to $15.3 \%$ in the Czech Republic; while levels in the Baltic States are over $30 \%$ (Latvia, $33.7 \%$; Estonia, $36.3 \%$ ).

Western banks made extraordinary profits in the region, with profit levels more than twice as high as in their home countries, and were expecting continued expansion in the region even when the financial crisis was just around the corner. An analysis by Deutsche Bank (Mühlberger, 2007), dated December 2007, saw a huge growth perspective for the central-east European banking sector, with an expansion of credit averaging $23 \%$ a year until 2011. For the south-east European banking sector, a corresponding yearly expansion of credit averaging $17 \%$ was foreseen. It also pointed to 
the under-developed nature of these banking systems as measured by the low levels of aggregated credit volumes compared to GDP ( $85 \%$ for central eastern Europe and $75 \%$ for south-east Europe), considering the usual levels in western Europe (for the Eurozone: $230 \%$ ).

The current situation is that, as a result of falling GDP, rising unemployment and weaker national currencies, the share of non-performing loans is rising and credit placements to central east European countries have become 'toxic assets' for western banks. Austrian banks have outstanding credits at their branch offices in eastern Europe of up to $80 \%$ of Austrian GDP. Eastern borrowers must repay $\$ 400 \mathrm{bn}$ in debt owed to western banks during 2009. Western headquarters (themselves in trouble) were reluctant to bail out their eastern affiliates and even to continue credit provision.

Emerging Europe has thus been hit hard by global de-leveraging and frozen crossborder bank lending. The impact has flowed through the same financial linkages with mature markets that previously allowed the region to build up a high degree of leverage through the rapid growth of foreign-financed credit. Cross-border bank funding is now being disrupted as the banking crisis in western Europe intensifies. Growth in credit to the private sector is falling rapidly, intensifying the vicious circle between output decline and deteriorating asset quality (IMF, 2009).

With household debt in several new member states (such as Hungary and Romania, for example), as well as in Serbia and the Ukraine, largely denominated in foreign exchange as a consequence of the 20-25\% currency devaluations (in Ukraine, up to $50 \%$ ), families face a level of debt servicing that is up to $25 \%$ higher than originally planned. According to a recent poll by Nielsen Research (Napi, 2009), 40 per cent of Hungarian adults have a bank loan, mostly denominated in foreign currency. In April 2009, 49 per cent thought it would require serious efforts to repay their debt while $11 \%$ thought they might be unable to do so. This is no longer just a problem of financial stability but a burning social issue.

\section{Deep economic and trade integration with the west}

In most of the region, growth and modernisation were largely driven by foreign direct investment. Levels of FDI stock reached nearly $100 \%$ of GDP in certain central east European countries (e.g. Estonia, Hungary and the Czech Republic), while the FDI stock in almost all of them is over $50 \%$ of GDP. According to the recent estimates of the Institute of International Finance, FDI flows to the region are likely to be reduced from \$393bn in 2007 to around \$220bn in 2009.

FDI was, on the one hand, an indispensable lever for modernisation, but it resulted in a dependent economic position with strategic decisions made at western company headquarters and profit repatriation practices having a negative impact on current account balances. This factor added to their vulnerability under stormy conditions.

Moreover, the economies of the new member states are integrated with the European and the world economy to a greater extent than most EU15 economies, and so are highly dependent on external demand. It had not been thought previously that the particular pattern of their economic and trade integration with western Europe - which relies to a great extent on manufacturing - might become a risk factor. The high dependence on exports of intermediary manufacturing products to western Europe and 
other developed economies is, in particular, the major factor currently depressing growth prospects (the export shares of central east European countries are shown in Table 1). The new member states from central eastern Europe, specifically the so-called Višegrad Four, are particularly exposed to the breakdown of demand from the west, particularly from Germany.

The large automobile production capacities established in the Višegrad Four are not only highly dependent on the economic cycle but also on their parent companies in western Europe (or in a few cases in Japan, Korea or the US). The electronic components industry (an important part of manufacturing not only in Višegrad Four countries and Romania but also in the Baltic States), and especially contract manufacturers, are even more exposed to economic cycles. These industries constitute a large part of the reshaped industrial landscape in the new member states, increasing their vulnerability to external shocks. Developments in Germany are crucially important for new member states in central eastern Europe as most industrial investments, and most of their industrial exports, involve Germany. The severe downturn in Germany, estimated by the latest forecast to be $-6 \%$ for 2009 , has had dramatic effects on most new member states.

A position of dependence also appears at the micro level, since a large part of the economies of central eastern Europe are dominated by foreign multinational enterprises whose strategic decisions are made at company headquarters in the west.

The new member state affiliates of western multinationals have adopted plant-level adjustment measures similar to those applied in their western European parent companies, but with a heavier hand and one less based on negotiations with the social partners. The plant-level impact of the crisis in central eastern Europe is also harder than in the west, as fewer cushioning tools for the shock - in terms of labour market policy and collective bargaining instruments - exist. Only Hungary and Bulgaria have hastily adopted a specific labour market policy measure, with public support, for shortened working time along the lines of schemes existing in a number of EU15 countries. No other central eastern European country has corresponding measures either in operation or at the planning stage (for more on the plant-level impact, see Glassner and Galgóczi, 2009).

\section{Policy responses}

European policy responses to the crisis in central eastern Europe were neither timely nor satisfactory, and the European Union has left the initiative to the International Monetary Fund. The most dramatic and immediate effects of the crisis on central eastern European countries were caused by the paralysis of the financial markets and required immediate intervention.

Hungary and Latvia - followed by Romania - had to turn to the IMF by the end of 2008 for an emergency loan in order to fend off the immediate consequences resulting from the financial turbulence and bottlenecks.

The conditionalities of the $€ 7.5 \mathrm{bn}$ IMF package for Latvia speak for themselves: a 20 per cent cut in wages in public administration and similar cuts in teachers' wages, pensions and health spending. In view of the deteriorating growth prospects and the 
likely failure to meet the agreed 5 per cent budget deficit target, further cuts were held to be necessary in order to gain access to another tranche of the loan.

In the case of Hungary, the $€ 20 \mathrm{bn}$ emergency credit package ( $€ 12.5 \mathrm{bn}$ IMF; $€ 6.5 \mathrm{bn}$ EU; and $€ 1$ bn World Bank) encompassed conditions for budget spending cuts, including pensions and social allowances, to meet a 2.9 per cent government deficit target. It is reasonable to raise conditions of sound finances for countries with a problematic past fiscal record, but the lack of differentiation and the rigidity of the application is threatening the objective of the whole operation. Demanding adherence to a deficit target below 3 per cent at times of further downward corrections of growth prospects, and when most of the Eurozone is maintaining substantially higher deficit levels to cope with the immediate effects of the crisis, cannot be seen as responsible policy.

Other financial support schemes were also initiated outside the framework of the EU, including a pledge of up to $€ 24$.5bn during 2009 and 2010 by the European Bank for Reconstruction and Development, the European Investment Bank and the World Bank in support of banking sectors and bank lending to enterprises in emerging Europe.

The reliance of the EU on the IMF is itself evidence of political weakness; an indirect admission that Europe lacks Union-wide financial institutions with sufficient clout to deliver effective bail-outs. Considering the IMF's record with regard to the consequences of its bail-outs in developing countries, even if the recently undergone learning process is taken into account, the conditionalities of the provision of such support pose risks to these countries' mid-term development and cannot be seen as based on values in line with the European idea.

The speeding-up of access to the resources of the European Social Fund was a useful measure but, given the magnitude of the crisis, cannot be regarded as any more than a symbolic gesture. The decision by the European Union to increase crisis support to non-euro members, albeit with adverse conditionalities, was welcome. In this regard, it was stated in the ETUC document to the Executive Committee (ETUC, 2009):

In exchange for foreign currency loans, countries are forced to cut anything that is social: wages, social spending, workers' rights, public services. Moreover, access to the Commission's $€ 25$ billion balance of payment fund is conditional upon respecting the IMF adjustment programme. European funds are being used to help the IMF to cut down the social dimension in Europe.

The lack of European-level co-ordination of national financial support measures for parent banks, to take account of the risk of introducing domestic biases that might stifle the timely resumption of banking inflows to their foreign subsidiaries, was also a failure which had adverse effects on the central eastern European region, where western banks have risky credit placements. The absence of clear rules for cross-border crisis management and burden-sharing raises uncertainty about the re-capitalisation of foreign-owned subsidiaries.

The decision of the EU summit at the end of February not to provide co-ordinated help to new member states in central eastern Europe was also a negative message to the region, just as it was also to the neighbouring south-east European and eastern European countries. 
The decision by the G20 substantially to increase the resources of the IMF and to provide other forms of finance to emerging markets (such as the Flexible Credit Line) is an important step; at the same time, it highlights the inability and paralysis of the EU, delivering the central east European region even more to the influence of non-EU policy. This cannot be seen as an excuse for the EU not to commit itself more decisively in favour of the troubled region.

\section{Concluding remarks}

We have identified a number of factors that lead the new member states of central eastern Europe to a particular exposure to the current economic crisis. Depending on the situation of the country in question, these different factors do, in some cases, combine into a toxic and explosive mix which has wide-ranging consequences for the whole of Europe.

A high reliance on external finances, as well as the indebtedness of the government, the population and enterprises, have made some of these countries especially vulnerable to external financial shock. On top of that, the high level of economic and trade integration means that a global shock is rapidly transmitted to national economies. Meanwhile, employment creation had never been a strong phenomenon in these countries, even in the years of high growth. Existing employment is less secure and welfare institutions afford less coverage. Mass unemployment and growing poverty is a real danger.

Beyond the financial aspects, the crisis has also had other serious effects, most of them arising from this high level of economic integration of the region. The current situation perfectly illustrates the adverse effects of economic integration without social and political integration. Weak social welfare systems in the central eastern European region are being further dismantled at a time when western Europe claims to be more resistant to the crisis than Anglo-Saxon economies due to the higher level of automatic stabilisers. Perversely, the discredited neo-liberal economic doctrine seems to have been further strengthened in the new member states, while developed western economies seem to be leaving it behind. All this is happening at the initiative, or with the support, of the European Commission. This strategy should be fundamentally revised.

Basic European values, such as solidarity and the idea of social Europe, have been undermined by the adverse conditionalities attached to its limited support by the EU (or where these have been simply left up to the IMF). People's faith, five years ago, that eastern enlargement of the EU would lead to economic and social convergence towards the rich EU15 member state economies has been seriously shaken.

Indeed, the lack of proper European responses to the crisis, with its severe impact on the new member states, could well call into question the very future of a united Europe, to say nothing of the prospects of further enlargement.

\section{References}

The Economist (2009) 'The whiff of contagion' 28 February, pp. 26-29.

ETUC (2009) The Crisis: Developments in Europe document to the Executive Committee, 17-18 March, Brussels. 
European Commission (2008) AMECO online data basis, Brussels.

European Commission (2009) Spring Economic Forecast May, Brussels.

Financial Times (2009a) 'Homeward bound' 30 April, p. 7.

Financial Times (2009b) 'East Europe's woes set to dominate EU summit' 27 February.

Glassner, V and B. Galgóczi (2009) Plant-level Responses to the Economic Crisis ETUI Working Paper 2009/1: Brussels.

Gros, D (2009) Collapse in Eastern Europe? CEPS Commentary, Centre for European Policy Studies, Brussels.

IMF (2009) Global Financial Stability Report April, Washington DC.

Mühlberger, Marion (2007) 'Südosteuropas Bankensektor rückt ins Rampenlicht' Deutsche Bank Research Aktuelle Themen 406, 19 December.

Napi (2009) Poll on failing household credits Napi daily economic news portal (in Hungarian), 18 May 2009 (www.napi.hu).

Shelburne, C. Robert (2008) Current Account Deficits in European Emerging Markets Discussion Paper Series No. 2, United Nations Economic Commission for Europe: Geneva.

Watt, A (2008) The economic and financial crisis in Europe: addressing the causes and the repercussions European Economic and Employment Policy Brief 2008/3, ETUI: Brussels. 